\title{
cis-Urocanic acid as a potential nickel(II) binding molecule in the human skin
}

\author{
Nina Ewa Wezynfeld, ${ }^{a}$ Wojciech Goch, ${ }^{a}$ Wojciech Bal, ${ }^{a}$ and Tomasz Frączyk ${ }^{* a}$ \\ Received (in $X X X, X X X)$ Xth $X X X X X X X X X 20 X X$, Accepted Xth $X X X X X X X X X 20 X X$ \\ ${ }_{5}$ DOI: 10.1039/c3dt53194e
}

cis-Urocanic acid, a derivative of histidine, is one of essential components of human skin. We found that it can bind nickel(II) ions in a pH-dependent manner, with the dissociation constant in the low millimolar range, as revealed by potentiometry, and confirmed by isothermal titration calorimetry and UV-vis spectroscopy. The binding occurs within the physiological skin $\mathrm{pH}$ range. Considering the fact that cis-

10 urocanic acid is present in the human skin in concentrations as high as millimolar, this molecule may be a physiologically important player in nickel trafficking in the human organism.

\section{Introduction}

Urocanic acid (UCA, 3-(1H-imidazol-4-yl)propenoic acid) is present in the uppermost layer of the skin (stratum corneum). It is 15 produced by histidine ammonia-lyase (histidase) from histidine as a trans isomer (trans-UCA, Scheme 1). As urocanate hydratase (urocanase), the enzyme which catabolizes trans-UCA, is not present in the skin, trans-UCA accumulates in the epidermis to $0.7 \%$ dry weight, which means that in live tissue its concentration 20 is millimolar. ${ }^{1}$ trans-UCA isomerizes to cis-urocanic acid (cisUCA) upon exposure to ultraviolet radiation (Scheme 1). The equilibrium concentration for cis-UCA reaches $60-70 \%$ of total epidermal UCA. ${ }^{2}$ Both UCA isomers are removed from the skin in sweat and by the desquamation process, however some UCA is 25 transported to blood and consequently to urine. ${ }^{3,4}$ UCA, as a component of Natural Moisturizing Factor (NMF), is involved in the regulation of $\mathrm{pH}$ of the skin and skin hydration. ${ }^{5,6}$ On the other hand, cis-UCA has been shown to play a role in photoimmunosuppresion $^{7-9}$ and photocarcinogenesis. $^{10}$ The 30 mechanisms of these actions are yet to be elucidated, however.

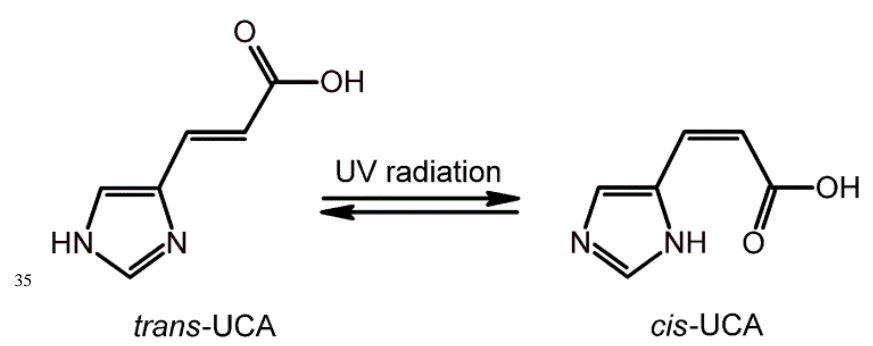

Scheme 1. Structures of trans-UCA and cis-UCA.

Allergy to nickel is one of the most common causes of allergic contact dermatitis. It is estimated that $10-15 \%$ of women in the 40 general population is sensitive to nickel. ${ }^{11}$ The mechanism of this condition has not yet been fully elucidated. One of the important unexplored factors is the first step of delivering $\mathrm{Ni}$ (II) to the organism. It is possible that a role in it is played by metal complexes with biomolecules present in the uppermost layers of 45 the skin.

Considering the similarity of cis-UCA and histidine we assumed that this molecule can bind $\mathrm{Ni}(\mathrm{II})$, as the ability of histidine to form strong $\mathrm{Ni}$ (II) complexes is well documented. ${ }^{12,13}$ Using UV-vis spectrophotometry, potentiometry and isothermal 50 titration calorimetry (ITC) we proved that cis-UCA molecule interacts with $\mathrm{Ni}$ (II) ions. We measured stoichiometry, stability constants, enthalpy and entropy of these interactions. Our results suggest a possibility of interaction of cis-UCA with $\mathrm{Ni}(\mathrm{II})$ in human skin.

55

\section{Experimental section}

\section{Chemicals and reagents}

cis-UCA and trans-UCA (purity $\geq 98 \%$ ) were obtained from ${ }_{60}$ Sigma-Aldrich. Nickel(II) nitrate hexahydrate, $99.999 \%$ trace metal basis, was obtained from Sigma-Aldrich. HEPES was obtained from Carl-Roth. Potassium nitrate(V) was purchased from Merck. Deionized, ultra-pure Milli-Q water was used for sample preparation. In order to prevent UCA isomerisation, all ${ }_{65}$ experiments were made with special care to protect samples from ambient light.

\section{UV-vis titrations}

Two types of UV-vis $\mathrm{pH}$ titrations were performed. In the first one, samples containing $0.1 \mathrm{mM}$ cis-UCA were titrated with ${ }_{70} \mathrm{NaOH}$ in the $\mathrm{pH}$ range of 4.7-9.8. In the second type, samples containing $4 \mathrm{mM}$ cis-UCA or trans-UCA, $2 \mathrm{mM} \mathrm{Ni}\left(\mathrm{NO}_{3}\right)_{2}$ and $100 \mathrm{mM} \mathrm{KNO}{ }_{3}$ were titrated with $\mathrm{NaOH}$ in the $\mathrm{pH}$ range of 2.68.0. The UV-vis spectra were obtained using a Lambda 950 UV/Vis/NIR spectrophotometer (Perkin Elmer) at $25^{\circ} \mathrm{C}$ over the 75 spectral range $200-850 \mathrm{~nm}$. 


\section{Potentiometric titrations}

Potentiometric titration were performed on a 907 Titrando automatic titrator (Metrohm), using a Biotrode combined glass electrode (Metrohm). The electrode was calibrated daily by nitric 5 acid titrations, ${ }^{14}$ and $100 \mathrm{mM} \mathrm{NaOH}$ (carbon dioxide free) was used as a titrant. Sample volumes of $1.5 \mathrm{~mL}$ were used. Samples were prepared by dissolving solid cis- or trans-UCA in $4 \mathrm{mM}$ $\mathrm{HNO}_{3} / 96 \mathrm{mM} \mathrm{KNO}_{3}$ to obtain a $4 \mathrm{mM}$ UCA concentration. The $\mathrm{Ni}$ (II) and cis-UCA/trans-UCA complex formation was studied 10 using samples in which the molar ratio of cis-UCA/trans-UCA to $\mathrm{Ni}$ (II) were: $2.2: 1,3.3: 1,4.4: 1$ and 6.7:1. All experiments were performed under argon at $25^{\circ} \mathrm{C}$, in the $\mathrm{pH}$ range of 2.7-11.0 for titration of cis- and trans-UCA, 2.7-8.0 for Ni(II) and cis-UCA, and 2.7-6.5 for $\mathrm{Ni}(\mathrm{II})$ and trans-UCA. The collected data were 15 analysed using the SUPERQUAD and HYPERQUAD programs. ${ }^{15,16}$ Five titrations were included simultaneously into calculations, separately for protonation and $\mathrm{Ni}(\mathrm{II})$ complexation.

\section{ITC titrations}

ITC experiments were carried out on the Nano ITC Standard ${ }_{20}$ Volume calorimeter (TA Instrument). The sample cell $(950 \mu \mathrm{L})$ was filled with UCA solution and the reference cell was filled with the Milli-Q water. The syringe $(250 \mu \mathrm{L})$ was loaded with a Ni(II) solution. The Milli-Q water was degassed under vacuum for $15 \mathrm{~min}$ before sample preparation. Furthermore, sample 25 solutions were degassed for $5 \mathrm{~min}$ before loading into the cell and the syringe. The cell solutions contained $5 \mathrm{mM}$ cis-UCA/transUCA, $100 \mathrm{mM}$ HEPES and $100 \mathrm{mM} \mathrm{KNO}_{3}$ at $\mathrm{pH}$ 7.4. The syringe solutions contained $25 \mathrm{mM}$ or $50 \mathrm{mM} \mathrm{Ni}\left(\mathrm{NO}_{3}\right)_{2}$ and 100 $\mathrm{mM} \mathrm{KNO}_{3}$. The $\mathrm{pH}$ values of the cell solution did not change 30 during titrations. The solutions in the cell were stirred at $170 \mathrm{rpm}$ by the syringe. Volumes of titrant injections were 2.57 or 4.00 $\mu \mathrm{L}$. Intervals between injections were $1000 \mathrm{~s}$ to allow complete equilibration of the system. The measurements were performed at 15,25 or $37{ }^{\circ} \mathrm{C}$ for cis-UCA and at $25{ }^{\circ} \mathrm{C}$ for trans-UCA.

35 Background titrations, consisting of the identical syringe solutions and the cell solutions except for cis-UCA/trans-UCA were subtracted from each experimental titration. The obtained data were analyzed with the SEDPHAT program (version 10.58d) utilizing the global fitting feature. ${ }^{17}$ The conditional complex 40 formation constants were calculated for the following equilibria:

$$
\begin{array}{ll}
K_{\mathrm{NiL}}: & N i^{2+}+U C A \rightleftarrows N i(U C A) \\
K_{\mathrm{NiL}_{2}}: & N i^{2+}+2 U C A \rightleftarrows N i(U C A)_{2}
\end{array}
$$

\section{Results and discussion}

45 The $\mathrm{pH}$ dependence of UV absorption of $c i s$-UCA is presented in Fig. 1. The most significant changes, observed at 250 and 290 $\mathrm{nm}$, allowed us to determine the $\mathrm{p} K_{\mathrm{a}}$ values for its carboxylate and imidazole groups, given in Table 1 . The maximum of absorption blueshifted from $269 \mathrm{~nm}$ to $263 \mathrm{~nm}$ for $\mathrm{pH} 1.7-4.7$ and 50 back, from $263 \mathrm{~nm}$ to $282 \mathrm{~nm}$ for $\mathrm{pH}$ 4.7-9.8. This shift was not significantly affected for $0.1 \mathrm{mM}$ cis-UCA by equimolar $\mathrm{Ni}(\mathrm{II}) \dagger$. However, for higher concentrations (4 mM cis-UCA and $2 \mathrm{mM}$ $\mathrm{Ni}(\mathrm{II})$ ), the $\mathrm{pH}$ dependent changes were observed in the regions specific for $\mathrm{Ni}$ (II) octahedral complexes $(\sim 390 \mathrm{~nm}$ and $\sim 650 \mathrm{~nm})$ 55 (Fig. 2). Such effects were seen neither for cis-UCA nor Ni(II) alone. For the cis-UCA/Ni(II) system the absorbance maxima blue-shifted from $391 \mathrm{~nm}$ to $383 \mathrm{~nm}$ and from $658 \mathrm{~nm}$ to $648 \mathrm{~nm}$. The molar absorption for those bands increased along with the increasing $\mathrm{pH}$. This effect is typical for substitutions of oxygen ${ }_{60}$ donors in the first coordination sphere of high-spin $\mathrm{Ni}$ (II) complexes with nitrogens. ${ }^{18}$ Above $\mathrm{pH} 8.0$ a green precipitate appeared in the sample. Dissolution of this precipitate at $\mathrm{pH} 5$ demonstrated that it was composed predominantly of $\mathrm{Ni}(\mathrm{OH})_{2}$, with traces of cis-UCA. Only minor changes in the spectra were 65 observed for a sample containing $4 \mathrm{mM}$ trans-UCA and $2 \mathrm{mM}$ $\mathrm{Ni}(\mathrm{II})$, compared to free trans-UCA, and the precipitation occurred at $\mathrm{pH}$ 6.5. This whitish precipitate was partially redissolved at $\mathrm{pH}$ 5. The UV-vis spectra demonstrated that it was composed largely of trans-UCA, but also contained significant 70 amount of $\mathrm{Ni}$ (II). There was no precipitation of trans-UCA seen in the absence of $\mathrm{Ni}(\mathrm{II})$. Therefore, most likely the precipitate was composed of $\mathrm{Ni}$ (trans-UCA) complex neutralized electrostatically by one $\mathrm{OH}^{-}$ion per $\mathrm{Ni}(\mathrm{II})$.
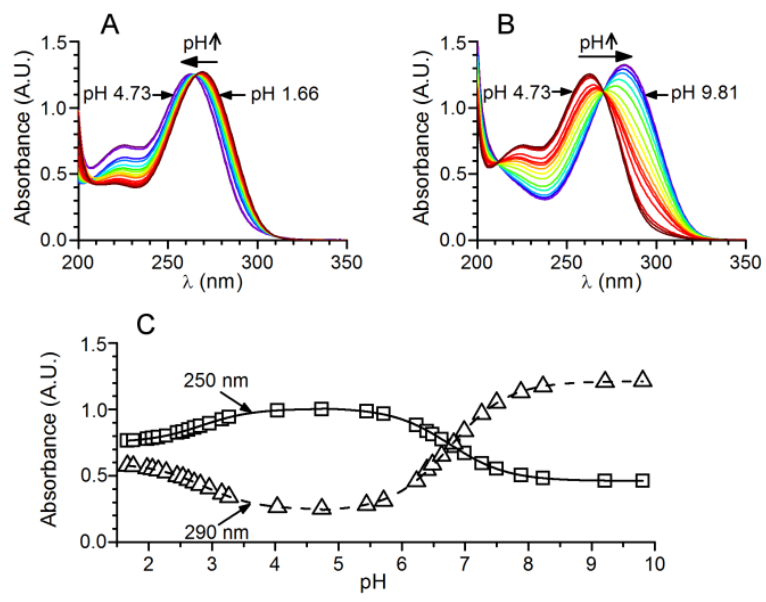

Fig. 1. The $\mathrm{pH}$ dependence of UV spectra of $0.1 \mathrm{mM}$ cis-UCA in $\mathrm{pH}$ 85 ranges of 1.66-4.73 (A) and 4.73-9.81 (B), and absorbance values of 0.1 $\mathrm{mM}$ cis-UCA at 250 and $290 \mathrm{~nm}(\mathrm{C})$.

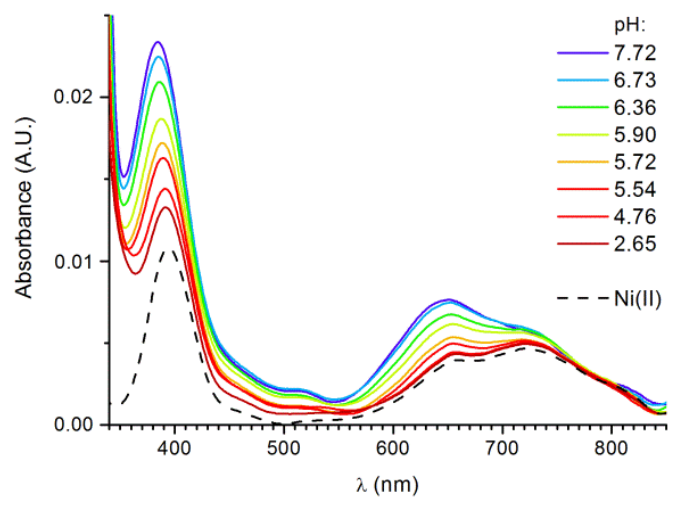

95

Fig. 2. Selected spectra of $\mathrm{Ni}(\mathrm{II})\left(2 \mathrm{mM} \mathrm{Ni}\left(\mathrm{NO}_{3}\right)_{2}\right.$, dashed line $)$ and its complexes with $c i s$-UCA $(4 \mathrm{mM})$. The $\mathrm{pH}$ values are indicated in the graph.

Potentiometric titrations of cis-UCA and trans-UCA alone and 100 with $\mathrm{Ni}(\mathrm{II})$ ions yielded protonation and $\mathrm{Ni}(\mathrm{II})$ complexation constants for both UCA isomers. They are presented in Tables 1 and 2 in the logarithmic form. Protonation constants for both ligands are in a satisfactory accordance with the literature data, 
obtained solely by UV-vis (lit., ${ }^{19} 3.43$ and 5.80 for trans-UCA, and 2.7 and 6.65 for $c i s$-UCA). The $\mathrm{p} K_{\mathrm{a}}$ values determined by potentiometry are also close to those obtained in our UV-vis titrations. The slight difference $(\Delta=0.07)$ in $\mathrm{p} K_{\mathrm{a}}$ values for the 5 carboxyl group is probably the result of difference in the ionic strength between these experiments.

Table 1. Logarithmic protonation constants $\left(\log \beta\right.$ and $\left.\mathrm{p} K_{\mathrm{a}}\right)$ for UCA isomers

\begin{tabular}{lccccc}
\hline \multirow{2}{*}{ Species } & \multicolumn{3}{c}{ cis-UCA } & \multicolumn{2}{c}{ trans-UCA } \\
& $\log \beta^{\mathrm{a}}$ & $\mathrm{p} K_{\mathrm{a}}{ }^{\mathrm{a}}$ & $\mathrm{p} K_{\mathrm{a}}{ }^{\mathrm{b}}$ & $\log \beta^{\mathrm{a}}$ & $\mathrm{p} K_{\mathrm{a}}{ }^{\mathrm{a}}$ \\
$\mathrm{H}_{2} \mathrm{~L}$ & $9.532(4)$ & 2.79 & $2.86(4)$ & $9.342(2)$ & 3.51 \\
$\mathrm{HL}$ & $6.744(2)$ & 6.74 & $6.76(4)$ & $5.830(1)$ & 5.83
\end{tabular}

${ }^{\text {a }}$ Values determined by potentiometry at $25^{\circ} \mathrm{C}$ and $I=0.1 \mathrm{M}$ $10\left(\mathrm{KNO}_{3}\right)$. Standard deviations on the least significant digits, provided by HYPERQUAD ${ }^{16}$ are given in parentheses.

${ }^{\mathrm{b}}$ Values determined by revealing the $\mathrm{pH}$ dependence of absorbance at 250 and $290 \mathrm{~nm}$ at $25^{\circ} \mathrm{C}$ for the experiment shown in Fig. 1. Standard deviations on the least significant digits are given in 15 parentheses.

Both cis-UCA and trans-UCA bind $\mathrm{Ni}(\mathrm{II})$ in the $1: 1$ and $1: 2$ metal to UCA ratios. The distributions of species for cis$\mathrm{UCA} /$ trans-UCA and $\mathrm{Ni}(\mathrm{II})$, calculated on the basis of 20 potentiometric constants are shown in Fig. 3. It is worth noting that the complex formation occurs in $\mathrm{pH}$ range specific for stratum corneum ( $\mathrm{pH} 5-6$ ), with the predominance of 1:1 complex, and is even more pronounced for deeper layers of the skin (pH 6-7.4), with higher amounts of 1:2 complex.

25 On the basis of potentiometric and UV-vis titration data, using the least square method, the spectra of $\mathrm{Ni}($ cis-UCA) and $\mathrm{Ni}(\text { cis-UCA })_{2}$ complexes were calculated and are shown in Fig. 4. The absorbance maxima for these complexes are $387\left(\varepsilon / \mathrm{dm}^{3}\right.$ $\left.\mathrm{mol}^{-1} \mathrm{~cm}^{-1} 10.5\right)$ and $658 \mathrm{~nm}(2.9)$, and, 380 (15.3) and $640 \mathrm{~nm}$ 30 (5.3), respectively. The blueshift of the bands for the latter complex is in agreement with the stronger ligand field effect exerted by the imidazole nitrogen of UCA vs. water molecules. ${ }^{18}$

35
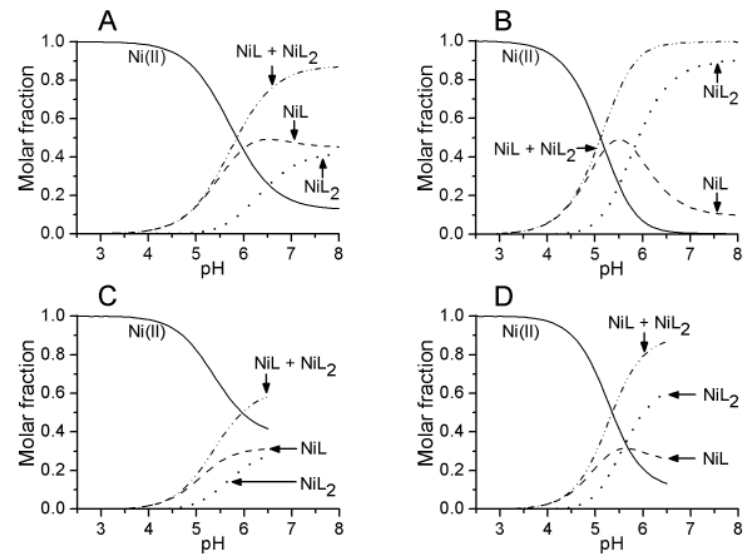

Fig. 3. Species distributions for $\mathrm{Ni}(\mathrm{II})$ complexes in a solution of $2 \mathrm{mM}$ $45 \mathrm{Ni}$ (II) and $4 \mathrm{mM}$ cis-UCA (A), $1 \mu \mathrm{M} \mathrm{Ni}$ (II) and $14 \mathrm{mM}$ cis-UCA (B), 2 $\mathrm{mM} \mathrm{Ni(II)} \mathrm{and} 4 \mathrm{mM}$ trans-UCA (C) and $1 \mu \mathrm{M} \mathrm{Ni(II)} \mathrm{and} 6 \mathrm{mM}$ trans-

UCA (D), based on potentiometric data shown in Tables 1 and 2.

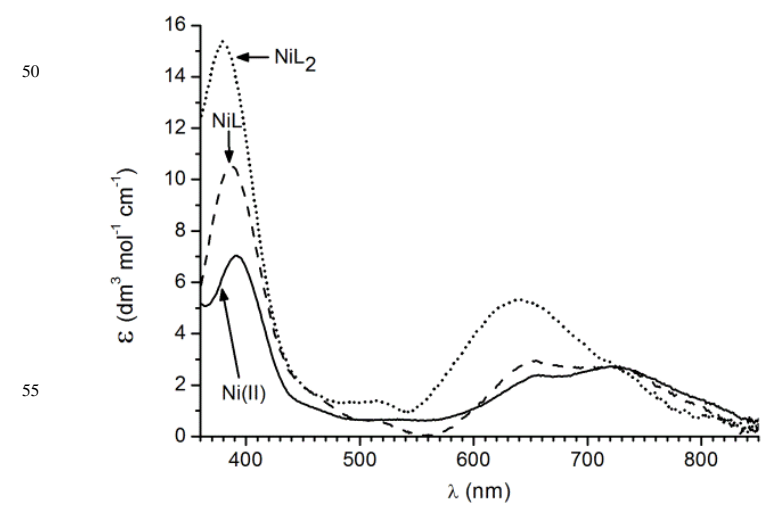

Fig. 4. Spectra of $\mathrm{Ni}\left(\right.$ cis-UCA) and $\mathrm{Ni}(\text { cis-UCA })_{2}$ complexes, calculated on the basis of potentiometric data shown in Tables 1 and 2, and UV-vis titration data shown in Fig. 2.

The analysis of relation between the complex stability and the ligand basicity for imidazole-type ligands can help reveal whether the chelate effect occurs or the ligand binds the metal ion monodentately by its imidazole nitrogen. ${ }^{20,21}$ Specifically, such ${ }_{65}$ dependence is linear for ligands with no chelating groups, and for $\mathrm{Ni}(\mathrm{II})$ and the ionic strength of $0.1 \mathrm{M}$ is described by the following equation:

$$
\log K_{N i L}^{N i}=0.225 p K_{H L}^{H}+1.380
$$

Such relation is shown in Fig. 5 for 1:1 Ni(II) complexes taken from the literature, ${ }^{20,22-26}$ and compared to our data for cis-UCA 70 and trans-UCA. The stability constant for trans-UCA is within the linear correlation observed for ligands interacting only by the imidazole part of the molecule (e.g. imidazole, 4methylimidazole). It means that only the imidazole nitrogen binds $\mathrm{Ni}$ (II) in trans-UCA. For cis-UCA the stability enhancement is 75 observed, although it is not as large as for e.g. histidine or histamine. It shows that also the carboxylic moiety participates in the interaction of cis-UCA with Ni(II). The carboxylate is not so effective in the stabilization of complex as the primary amine in histamine or the secondary amine in 4-(280 methylaminoethyl)imidazole. The $\mathrm{Ni}($ cis-UCA) complex is also not so stable as complexes with imidazole-4-acetic acid, which correlates with the higher stability of 6-membered chelates over the 7-membered one which we propose here (Fig 6).

The binding of the second molecule of cis-UCA compared to 85 the first one is weaker by $0.58 \log$ units $\left(\log \beta_{\mathrm{NiL} 2}-\log \beta_{\mathrm{NiL}}\right)$. The nature of this effect is largely statistical, because this difference is only slightly different from the statistical factor of 0.38 , resulting from the decreased number of bidentate binding modes for the second ligand molecule (10) vs. the first one (24). 90 The bigger difference is probably due to the repulsion between the carboxyl groups of the two cis-UCA molecules.

The analogous statistical factor for the monodentate binding of the second trans-UCA molecule is much lower and equal to 0.08 $(\log (6 / 5))$. This explains almost the same binding stability of the 95 first and the second trans-UCA molecule. 


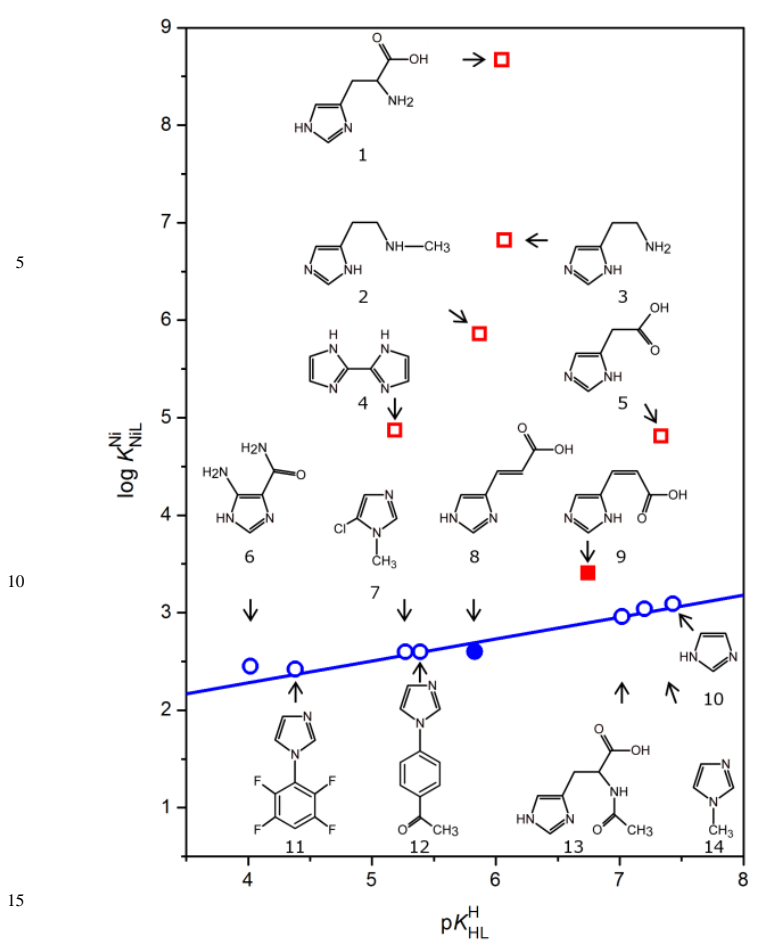

Fig. 5. The relation between the Ni(II) complex stability and the ligand basicity for imidazole-type ligands, shown for 1:1 Ni(II) complexes taken from the literature,$^{21}$ and compared to our data for cis-UCA and trans-

20 UCA. The blue line represents linear dependence for ligands binding $\mathrm{Ni}$ (II) monodentately by the imidazole nitrogen (blue circles) described by the equation: $\log K_{N i L}^{N i}=0.225 p K_{H L}^{H}+1.380$, valid for the $0.1 \mathrm{M}$ ionic strength. ${ }^{19,20}$ Ligands with chelating groups (red squares) show stability enhancement. Data shown are for histidine ${ }^{22}(1), 4-(2-$

25 methylaminoethyl)imidazole ${ }^{23}(2)$, histamine ${ }^{24}(3), 2,2^{\prime}$-biimidazole ${ }^{25}(4)$, imidazole-4-acetate ${ }^{25}$ (5), 4(5)-aminoimidazole-5(4)-carboxamide ${ }^{25}(6), 5$ chloro-1-methylimidazole ${ }^{20}$ (7), trans-UCA (8), cis-UCA (9), imidazole ${ }^{20,24}(10), \mathrm{N}-\left(2,3,5,6\right.$-tetrafluorophenyl)imidazole ${ }^{20}(11), 4$ '(imidazol-1-yl)acetophenone ${ }^{20}(12)$, acetylhistidine ${ }^{26}(13)$ and 1-

30 methylimidazole $^{20}(14)$.

35

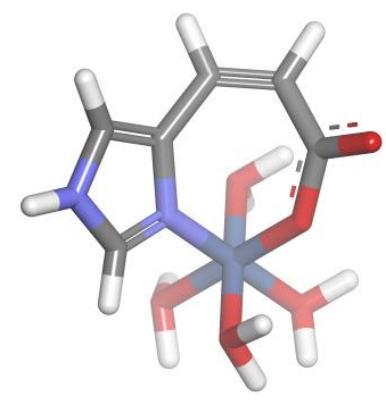

Fig. 6. The proposed structure of the Ni(cis-UCA) complex. Shown are $40 \mathrm{Ni}$ (II), cis-UCA and four water molecules in an octahedral complex.

ITC experiments were conducted at 15,25 and $37{ }^{\circ} \mathrm{C}$ for cis$\mathrm{UCA}$ and at $25{ }^{\circ} \mathrm{C}$ for trans-UCA, at $\mathrm{pH}$ 7.4. The results are presented in Tables 2 and 3. Temperature influences only slightly the logarithmic stability constants for $\mathrm{Ni}($ cis-UCA) and $\mathrm{Ni}$ (cis$\left.{ }_{45} \mathrm{UCA}\right)_{2}$ complexes and the binding enthalpy and entropic contribution
$(-\mathrm{T} \Delta \mathrm{S})$ for the $1: 1$ complex. The binding enthalpy for the $\mathrm{Ni}$ (cis$\mathrm{UCA})_{2}$ complex is higher at lower temperatures. On the other hand, the entropic contribution is higher at higher temperatures ${ }_{50}$ for the $\mathrm{Ni}(\text { cis-UCA })_{2}$ complex. In the result, the decrease of enthalpy at higher temperatures is compensated by the increase of the entropic contribution, which is reflected in Gibbs energy values. The formation of $\mathrm{Ni}$ (II) complexes with cis-UCA is energetically more favoured compared to trans-UCA in the same 55 conditions.

$\mathrm{Ni}$ (II) complex formation constants are higher for cis-UCA than for trans-UCA, as revealed by both potentiometry and ITC. All values obtained for $25{ }^{\circ} \mathrm{C}$ by ITC are lower when compared with those obtained by potentiometry at the same temperature. ${ }_{60}$ The probable reason for this is the different ionic strength used in ITC $(0.15 \mathrm{M})$ and the presence of HEPES buffer in these samples.

Table 2. Logarithmic Ni(II) complex formation constants for UCA isomers

\begin{tabular}{lcccccc}
\hline \multirow{2}{*}{ Species } & \multicolumn{4}{c}{ cis-UCA } & \multicolumn{2}{c}{ trans-UCA } \\
& $15{ }^{\circ} \mathrm{C}$ & \multicolumn{2}{c}{$25^{\circ} \mathrm{C}$} & $37^{\circ} \mathrm{C}$ & \multicolumn{2}{c}{$25^{\circ} \mathrm{C}$} \\
& $\log \mathrm{K}^{\mathrm{a}}$ & $\log \mathrm{K}^{\mathrm{a}}$ & $\log \beta^{\mathrm{b}}$ & $\log \mathrm{K}^{\mathrm{a}}$ & $\log \mathrm{K}^{\mathrm{a}}$ & $\log \beta^{\mathrm{b}}$ \\
$\mathrm{NiL}$ & $3.09(4)$ & $3.09(2)$ & $3.406(4)$ & $3.13(3)$ & $2.53(3)$ & $2.599(7)$ \\
$\mathrm{NiL}_{2}$ & $5.72(8)$ & $5.61(3)$ & $6.239(4)$ & $5.61(8)$ & $4.04(7)$ & $5.272(7)$
\end{tabular}

${ }_{65}{ }^{\text {a }}$ Conditional association constant values determined by ITC at 15, 25 and $37^{\circ} \mathrm{C}$, in $0.1 \mathrm{M} \mathrm{KNO}_{3}, 0.1 \mathrm{M}$ HEPES and $\mathrm{pH}$ 7.4. Standard deviations on the least significant digits, provided by SEDPHAT $^{17}$ are given in parentheses.

${ }^{\mathrm{b}}$ Values determined by potentiometry at $25^{\circ} \mathrm{C}$ and $I=0.1 \mathrm{M}$ $70\left(\mathrm{KNO}_{3}\right)$. Standard deviations on the least significant digits, provided by HYPERQUAD $^{16}$ are given in parentheses.

Table 3. Thermodynamic parameters for Ni(II) complexation determined

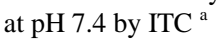

$\begin{array}{ccccc} & & \text { cis-UCA } & & \text { trans-UCA } \\ & 15^{\circ} \mathrm{C} & 25^{\circ} \mathrm{C} & 37^{\circ} \mathrm{C} & 25^{\circ} \mathrm{C} \\ \Delta \mathrm{H}_{\mathrm{NiL}} & -18.6(0.2) & -18.2(0.1) & -18.4(0.4) & -20.0(0.3) \\ \Delta \mathrm{H}_{\mathrm{NiL}_{2}} & -26.7(1.6) & -22.7(0.7) & -18.5(2.4) & -20.5(0.1) \\ -\mathrm{T} \Delta \mathrm{S}_{\mathrm{NiL}_{2}} & 1.5 & 0.6 & -0.2 & 5.6 \\ -\mathrm{T} \Delta \mathrm{S}_{\mathrm{NiL}_{2}} & -4.8 & -9.4 & -15.7 & -2.5 \\ \Delta \mathrm{G}_{\mathrm{NiL}_{\mathrm{iL}}} & -17.1 & -17.6 & -18.6 & -14.4 \\ \Delta \mathrm{G}_{\mathrm{NiL}} & -31.5 & -32.1 & -34.2 & -23\end{array}$

$75 \quad{ }^{\mathrm{a}}$ The values are presented in $\mathrm{kJ} \mathrm{mol}^{-1}$. Standard deviations on the least significant digits, provided by SEDPHAT ${ }^{17}$ are given in parentheses.

Of note are higher Gibbs energy values for $\mathrm{NiL}_{2}$ complexes 80 compared with NiL, which is in agreement with absorbance maxima being shifted to shorter wavelengths for $\mathrm{Ni}(\text { cis-UCA })_{2}$ complex, reflecting the presence of two nitrogen ligands in $\mathrm{NiL}_{2}$ complexes.

We showed that both UCA isomers can bind Ni(II) ions with 85 moderate affinity, with a stronger effect visible for cis-UCA. Of note is a correlation between concentration values in the stratum corneum of cis-UCA and $\mathrm{Ni}(\mathrm{II})$ ions upon the contact with the nickel-releasing material, which are the highest in this part of the skin. Considering these facts we propose that urocanic acid, 90 especially the cis isomer, can be Ni(II) binding molecule in the human skin. Based on the literature ${ }^{27,28}$ we estimated concentrations of main components of NMF as $43 \mathrm{mM}$ of serine, 
$30 \mathrm{mM}$ of glycine, $23 \mathrm{mM}$ of pyroglutamic acid, $18 \mathrm{mM}$ of alanine, $14 \mathrm{mM}$ of lactic acid, $14 \mathrm{mM}$ of cis-UCA and $6 \mathrm{mM}$ of trans-UCA. Concentrations of nickel can be estimated taking as the reference the maximum value, allowed by the European ${ }_{5}$ Union Nickel Directive (Directive 94/27/EC) for the release of this metal from products intended to come into direct, prolonged contact with skin, being equal to $0.5 \mu \mathrm{g} \mathrm{cm}{ }^{-2}$ per week. ${ }^{11}$ Locally this concentration can probably easily reach a micromolar level in the stratum corneum, especially because some kinds of jewelry 10 and coins release 100 times more nickel than allowed by the Directive. ${ }^{29,30}$ Taking the protonation constants and stability constants of $\mathrm{Ni}(\mathrm{II})$ complexes from the literature $\mathrm{e}^{26,31,32}$ and from this paper we calculated the distribution of $\mathrm{Ni}(\mathrm{II})$ species for above concentrations of ligands and of $1 \mu \mathrm{M}$ nickel ions (Fig. 7).

${ }_{15}$ At $\mathrm{pH} 5.622 \%$ of $\mathrm{Ni}(\mathrm{II})$ is complexed with cis-UCA, which places this molecule as the second binding compound, after serine. $10 \%$ of $\mathrm{Ni}(\mathrm{II})$ is in complex with trans-UCA. At $\mathrm{pH} 6.5$, still $22 \%$ of $\mathrm{Ni}$ (II) is bound with cis-UCA, after serine. The formation of $\mathrm{Ni}(\mathrm{II})-\mathrm{UCA}$ complexes can be even more 20 pronounced following the intended use of cis-UCA as a component of pharmaceuticals. Topical application of cis-UCA has been proposed as a safe and effective way to treat inflammatory skin disorders. ${ }^{89}$ Deeper investigation is needed as it was shown that cis-UCA can form a complex with human 25 serum albumin (HSA), ${ }^{33}$ another Ni(II)-binding biomolecule. ${ }^{34}$ The general important issue which remains to be resolved is whether cis-UCA plays a role of a transporting or rather a buffering agent for $\mathrm{Ni}(\mathrm{II})$ ions in the human organism.

30

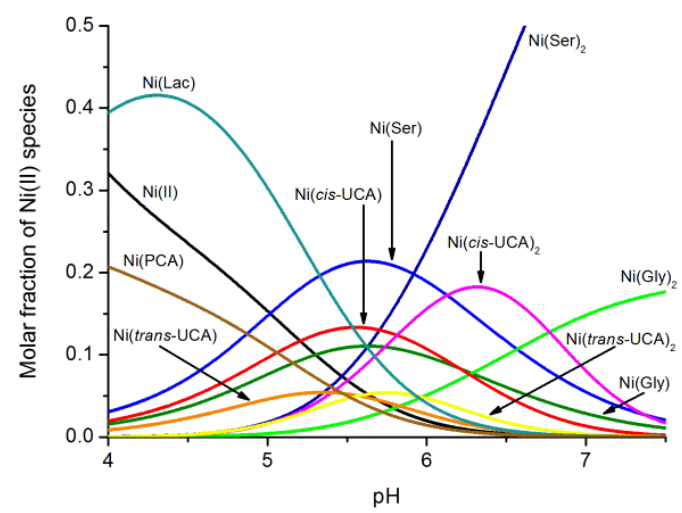

Fig. 7. $\mathrm{Ni}(\mathrm{II})$ species distribution simulated for $\mathrm{NMF}$ and $1 \mu \mathrm{M} \mathrm{Ni}^{2+}$ ions.

The protonation constants and stability constants of $\mathrm{Ni}(\mathrm{II})$ complexes 40 were taken from the literature $e^{26,31,32}$ and from this paper. Concentrations taken for calculations are $43 \mathrm{mM}$ serine, $30 \mathrm{mM}$ glycine, $23 \mathrm{mM}$ pyroglutamic acid (PCA), $18 \mathrm{mM}$ alanine, $14 \mathrm{mM}$ lactic acid (Lac), 14 $\mathrm{mM}$ cis-UCA and $6 \mathrm{mM}$ trans-UCA. ${ }^{27,28}$ The binding of $\mathrm{Ni}$ (II) by alanine in this conditions is negligible and omitted for clarity.

45

\section{Conclusions}

We proved that cis-UCA molecule interacts with $\mathrm{Ni}$ (II) ions with moderate stability, the complexes being strong enough to exist in physiological conditions in the outermost layers of the human ${ }_{50}$ skin, with consequences for nickel toxicity.

\section{Acknowledgements}

This work was supported in part by the project "Metal dependent 55 peptide hydrolysis. Tools and mechanisms for biotechnology, toxicology and supramolecular chemistry" carried out as part of the Foundation for Polish Science TEAM/2009-4/1 program, cofinanced from European Regional Development Fund resources within the framework of Operational Program Innovative ${ }_{60}$ Economy. The equipment used was sponsored in part by the Centre for Preclinical Research and Technology (CePT), a project co-sponsored by European Regional Development Fund and Innovative Economy, The National Cohesion Strategy of Poland.

\section{${ }_{65}$ Notes and references}

${ }^{a}$ Institute of Biochemistry and Biophysics, Polish Academy of Sciences, Pawińskiego 5a, 02-106 Warsaw, Poland. Fax: +48 22 659 4636; Tel:

+48 22592 5766; E-mail: tfraczyk@ibb.waw.pl

$\dagger$ Such low concentrations were chosen due to the high absorption 70 coefficients of UCA chromophores.

1 T. Mohammad, H. Morrison and H. HogenEsch, Photochem. Photobiol., 1999, 69, 115.

2 N. K. Gibbs, J. Tye and M. Norval, Photochem. Photobiol. Sci., $2008,7,655$.

753 A. M. Moodycliffe, M. Norval, I. Kimber and T. J. Simpson, Immunology, 1993, 79, 667.

4 A. Kammeyer, S. Pavel, S. S. Asghar, J. D. Bos and M. B. M. Teunissen, Photochem. Photobiol., 1997, 65, 593.

5 P. M. Krien and M. Kermici, J. Invest. Dermatol., 2000, 115, 414

806 S. Kezic, A. Kammeyer, F. Calkoen, J. W. Fluhr and J. D. Bos, Br. J. Dermatol., 2009, 161, 1098.

7 M. Norval and A. A. El-Ghorr, Methods, 2002, 28, 63.

8 M. V. Dahl, G. N. McEwen Jr and H. I. Katz, Photodermatol. Photoimmunol. Photomed., 2010, 26, 303.

859 J. K. Laihia, P. Taimen, H. Kujari and L. Leino, Br. J. Dermatol., 2012, 167, 506.

10 S. Beissert, D. Ruhlemann, T. Mohammad, S. Grabbe, A. El-Ghorr, M. Norval, H. Morrison, R. D. Granstein and T. Schwarz, J. Immunol., 2001, 167, 6232.

9011 S. Garg, J. P. Thyssen, W. Uter, A. Schnuch, J. D. Johansen, T. Menne, A. Belloni Fortina, B. Statham and D. J. Gawkrodger, Br. J. Dermatol., 2013, 169, 854.

12 Y. Zhang, S. Akilesh and D. E. Wilcox, Inorg. Chem., 2000, 39, 3057.

9513 G. Garrido, C. Rafols and E. Bosch, Talanta, 2011, 84, 347.

14 H. Irving, M. G. Miles and L. D. Pettit, Anal. Chim. Acta, 1967, 38, 475.

15 P. Gans, A. Sabatini and A. Vacca, J. Chem. Soc., Dalton Trans., $1985,1195$.

10016 P. Gans, A. Sabatini and A. Vacca, Talanta, 1996, 43, 1739.

17 J. C. D. Houtman, P. H. Brown, B. Bowden, H. Yamaguchi, E. Appella, L. E. Samelson and P. Schuck, Protein Sci., 2007, 16, 30.

18 H. Sigel and R. B. Martin, Chem. Rev., 1982, 82, 385.

19 P. Juusola, P. Minkkinen, L. Leino and J. K. Laihia, Monatsh. Chem., $105 \quad 2007, \mathbf{1 3 8}, 951$.

20 L. E. Kapinos, B. Song and H. Sigel, Inorg. Chim. Acta, 1998, 280, 50 .

21 H. Sigel, A. Saha, N. Saha, P. Carloni, L. E. Kapinos and R. Griesser, J. Inorg. Biochem., 2000, 78, 129.

11022 A. Krężel and W. Bal, Chem. Res. Toxicol., 2004, 17, 392.

23 A. Braibanti, F. Dallavalle, E. Leporati and G. Mori, J. Chem. Soc., Dalton Trans., 1973, 2539.

24 S. Sjoberg, Pure Appl. Chem., 1997, 69, 1549.

25 I. Torok, P. Surdy, A. Rockenbauer, L. Korecz Jr, G. J. A. A. Koolhaas and T. Gajda, J. Inorg. Biochem., 1998, 71, 7.

26 Y. Yamada, N. Nakasuka and M. Tanaka, Inorg. Chim. Acta, 1991, $\mathbf{1 8 5}, 49$. 
27 M. O. Visscher, G. T. Tolia, R. R. Wicket and S. B. Hoath, J. Cosmet. Sci., 2003, 54, 289.

28 A. V. Rawlings and C.R. Harding, Dermatol. Ther., 2004, 17, 43.

29 F. O. Nestle, H. Speidel and M. O. Speidel, Nature, 2002, 419, 132.

530 A. Schunch, J. Wolter, J. Geier and W. Uter, Contact Dermatitis, $2011,64,142$.

31 A. E. Martell and R. M. Smith, in Critical stability constants, Plenum Press, New York 1982, vol. 5.

32 R. Portanova, L. H. J. Lajunen, M. Tolazzi and J. Piispanen, Pure 10 Appl. Chem., 2003, 75, 495.

33 B. Schwarzinger and H. Falk, Monatsh. Chem., 2004, 135, 1297.

34 W. Bal, J. Christodoulou, P. J. Sadler and A. Tucker, J. Inorg. Biochem., 1998, 70, 33. 